\title{
PENGARUH TERAPI BERMAIN CLAY TERHADAP KECEMASAN PADA ANAK USIA PRA SEKOLAH (3-6 TAHUN) YANG MENJALANI HOSPITALISASI DI RUMAH SAKIT BENGKULU
}

\author{
Yeni Eliyanti' ${ }^{1}$, Yenni Fusfitasari ${ }^{2)}$ \\ 1,2Program Profesi Ners, Program Studi Keperawatan STIKES Bhakti Husada \\ Bengkulu \\ E-mail: yenieliyanti@yahoo.co.id /yen.fus@gmail.com
}

\begin{abstract}
Problems: Anxiety is the most common feeling experienced by pediatric patients who are undergoing hospitalization. The Aim Of The Research : Knowing the effect of playing clay therapy on anxiety in pre-school aged children (3-6 years) undergoing hospitalization at Harapan and Do'a Hospital Bengkulu City. Research Method : The type of research used is a pre-experimental design using a pre and post-test design with a one group pre-test-post-test design, the sampling technique in this study uses a purposive sampling technique. The Results: The results showed that the average value of anxiety in pre-school age children (3-6 years) who underwent hospitalization before playing clay therapy with an average value of anxiety was 11.75 . The results showed that the average value of anxiety in pre-school age children (3-6 years) who underwent hospitalization after playing clay therapy with an average value of anxiety was 8.60. The results of statistical tests obtained $p$ value $=0.000$, meaning $<0.05(\alpha)$ so it can be concluded that there is an effect of playing clay therapy on anxiety in pre-school age children (3-6 years) undergoing hospitalization at Bengkulu Hospital. Conclusions: The results of the study concluded that there was a decrease in the average value of anxiety in pre-school age children (3-6 years) who underwent hospitalization before and after playing clay therapy and by looking at the statistical value it was found that there was an effect of playing clay therapy on anxiety in pre-school age children. (3-6 years) who underwent hospitalization at Bengkulu Hospital.
\end{abstract}

Keywords: Clay Play Therapy, Anxiety, Preschool Children (3-6 years), Hospitalization.

\begin{abstract}
ABSTRAK
Permasalahan: Kecemasan merupakan perasaan yang paling umum dialami oleh pasien anak yang sedang mengalami hospitalisasi. Tujuan Penelitian: Mengetahui pengaruh terapi bermain clay terhadap kecemasan pada anak usia pra sekolah (3-6 tahun) yang menjalani hospitalisasi di Rumah Sakit Bengkulu. Metode Penelitian: Jenis penelitian yang digunakan adalah pre eksperimental design menggunakan pre dan post test design dengan rancangan one group pre test-post test, teknik pengambilan sampel dalam penelitian menggunakan teknik purposive sampling. Hasil: Hasil penelitian didapatkan nilai rata-rata kecemasan pada anak usia pra sekolah (3-6 tahun) yang menjalani hospitalisasi sebelum terapi bermain clay dengan nilai rata-rata kecemasan adalah 11.75 . Hasil penelitian didapatkan nilai rata-rata kecemasan pada anak usia pra sekolah (3-6 tahun) yang menjalani hospitalisasi setelah terapi bermain clay dengan nilai rata-rata kecemasan adalah 8.60. Hasil uji statistik didapatkan nilai $p=0,000$, berarti $<0,05(\alpha)$ sehingga dapat disimpulkan bahwa ada pengaruh terapi bermain clay terhadap kecemasan pada anak usia pra sekolah (3-6 tahun) yang menjalani hospitalisasi di Rumah Sakit Bengkulu. Kesimpulan: Hasil penelitian dapat disimpulkan terdapat penurunan nilai rata-rata kecemasan pada anak usia pra sekolah (36 tahun) yang menjalani hospitalisasi sebelum dan setelah terapi bermain clay dan dengan melihat nilai statistik didapatkan bahwa ada pengaruh terapi bermain clay terhadap kecemasan pada anak usia pra sekolah (3-6 tahun) yang menjalani hospitalisasi di Rumah Sakit Bengkulu.
\end{abstract}

Kata Kunci : Terapi Bermain Clay, Kecemasan, Anak Pra Sekolah (3-6 tahun), Hospitalisasi. 


\section{PENDAHULUAN}

Masalah kesehatan dunia yang menjadi prioritas WHO (World Health Organization) saat ini, yakni menyelesaikan agenda kesehatan MDGs (Miilenium Develepment Goals) yang belum selesai. Agenda yang terdapat pada MDGs tersebut dikembangkan kembali dalam agenda kesehatan SDGs (Sustainable Development Goals) hingga tahun 2030. Adapun agenda kesehatan yang terdapat didalam SDGs meliputi Kesehatan ibu, kesehatan anak, penyakit menular, dan kesehatan lingkungan (World Health Organition, 2015).

Angka hospitalisasi yang tinggi yaitu $15,26 \%$ ditunjukkan dengan selalu penuhnya ruangan anak baik rumah sakit pemerintah maupun swasta yang dapat menimbulkan kecemasan hospitalisasi pada anak, sehingga rumah sakit perlu menyediakan fasilitas agar anak dapat menyesuaikan diri dengan lingkungan baru salah satu yang dapat rumah sakit gunakan adalah terapi bermain. Terapi bermain merupakan salah satu terapi yang dilakukan oleh anak untuk mengatasi kesulitan, tekanan dan tantangan yang dihadapi sehingga kecemasan pada anak dapat teratasi (Yati et al., 2017).

Anak yang mengalami hospitalisasi merupakan suatu hal baru yang dialami bagi sebagian anak. Perubahan fisik maupun emosional pada anak terjadi dikarenakan penyesuaian diri anak terhadap lingkungan yang baru, sehingga menimbulkan suatu tekanan emosional baik anak maupun orang tua. Anak dapat mengalami fobia, panik dan cemas karena adanya perubahan secara fisik maupun emosionalnya (Daniel, 2021).

Kecemasan merupakan perasaan yang paling umum dialami oleh pasien anak yang sedang mengalami hospitalisasi. Kecemasan yang sering dialami seperti menangis, dan takut pada orang baru. Banyaknya stressor yang dialami anak ketika menjalani hospitalisasi menimbulkan dampak negatif yang mengganggu perkembangan anak. Lingkungan rumah sakit dapat merupakan penyebab stress dan kecemasan pada anak (Marni, 2018).

Terapi bermain merupakan terapi yang digunakan agar mengurangi kecemasan ketakutan dan anak dapat mengenal lingkungan, serta belajar mengenai perawatan serta prosedur yang dilakukan oleh staf rumah sakit (Daniel, 2021). Permainan pada anak prasekolah dapat diterapkan dengan melakukan skill play. Terapi bermain skill play 
terdapat juga permainan membentuk (Konstruksi) suatu kreasi seperti clay. Tingkat kecemasan anak akibat hospitalisasi dengan menggunakan terapi bermain (Alini, 2017).

Tujuan penelitian adalah mengetahui pengaruh terapi bermain clay terhadap kecemasan pada anak usia pra sekolah (3-6 tahun) yang menjalani hospitalisasi di Rumah Sakit Bengkulu.

\section{METODE PENELITIAN}

Jenis penelitian yang digunakan adalah pre eksperimental design menggunakan pre dan post test design dengan rancangan one group pre test-post test, dimana rancangan ini mengungkapakan sebab akibat dengan cara melibatkan satu kelompok subjek. Kelompok subjek diobservasi sebelum dilakukan intervensi dan diobservasi lagi setelah intervensi (Notoatmodjo, 2016). Perlakuan yang diberikan berupa intervensi terapi bermain clay dan pengukuran (O1 dan $\mathrm{O} 2)$ yang dilakukan adalah kecemasan pada anak usia pra sekolah (3-6 tahun).

Populasi dalam penelitian ini adalah semua pasien anak yang berusia 3-6 tahun yang dirawat di Rumah Sakit Bengkulu tahun 2020 sebanyak 105 orang. Jumlah anggota sampel masing-masing 10 sampai dengan 20, maka sampel yang akan diteliti berjumlah 20 orang dengan teknik pengambilan sampel menggunakan tehnik purposive sampling, yakni adalah teknik penentuan sampel atas pertimbangan tertentu yang dikehendaki peneliti. Dengan kriteria inklusi yaitu anak yang kooperatif dan dengan kesadaran kesadaran baik (composmentis), anak yang ditunggu orang tuanya atau keluarganya.

Instrumen penilaian kecemasan menggunakan hospital anxiety depression scale $(H A D S)$. Intervensi dalam penelitian ini dilakukan pada anak yang dirawat di ruang perawatan anak. Anak yang dirawat dilakukan penilaian kecemasan dengan menggunakan kuesioner $H A D S$ untuk mendapatkan nilai kecemasan pretest, setelah itu dilakukan terapi bermain clay selama 30 menit dan dilakukan penilaian kembali kecemasan dengan menggunakan kuesioner $H A D S$ untuk mendapatkan nilai kecemasan posttest. Data disajikan dalam mendistribusikan melalui analisis univariat dan analisis bivariat. Pengujian hipotesis penelitian menggunakan uji $\mathrm{T}$, jika $\mathrm{t} \leq 0,05$, berarti ada 
pengaruh terapi bermain clay terhadap kecemasan pada anak usia pra sekolah (3-6 tahun) yang menjalani hospitalisasi di Rumah Sakit Bengkulu (Dahlan, 2014).

\section{HASIL}

Tabel 1. Nilai rata-rata kecemasan pada anak usia pra sekolah (3-6 tahun) yang menjalani hospitalisasi sebelum terapi bermain clay di Rumah Sakit Bengkulu

\begin{tabular}{|c|c|c|c|c|}
\hline & Mean & $\begin{array}{c}\text { Standar } \\
\text { Deviasi }\end{array}$ & $\begin{array}{l}\text { 95\% Confidence } \\
\text { Interval }\end{array}$ & $\begin{array}{l}\text { Minimum- } \\
\text { Maksimum }\end{array}$ \\
\hline $\begin{array}{l}\text { Kecemasan pada anak } \\
\text { usia pra sekolah ( } 3-6 \\
\text { tahun) yang menjalani } \\
\text { hospitalisasi sebelum } \\
\text { terapi bermain clay }\end{array}$ & 11.75 & 1.293 & 11.15 sampai 12.35 & $10-14$ \\
\hline
\end{tabular}

Berdasarkan tabel $1 \mathrm{di}$ atas kecemasan pada anak usia pra sekolah (3-6 tahun) yang menjalani hospitalisasi sebelum terapi bermain clay dengan nilai rata-rata kecemasan adalah 11.75 .

Tabel 2. Nilai rata-rata kecemasan pada anak usia pra sekolah (3-6 tahun) yang menjalani hospitalisasi setelah terapi bermain clay di Rumah Sakit Bengkulu

\begin{tabular}{lcccc}
\hline & Mean & $\begin{array}{c}\text { Standar } \\
\text { Deviasi }\end{array}$ & $\begin{array}{c}\text { 95\% Confidence } \\
\text { Interval }\end{array}$ & $\begin{array}{c}\text { Minimum- } \\
\text { Maksimum }\end{array}$ \\
\hline $\begin{array}{l}\text { Kecemasan pada anak } \\
\text { usia pra sekolah (3-6 }\end{array}$ & & 1.698 & 7.81 sampai 9.39 & $6-12$ \\
tahun) yang menjalani & & & & \\
hospitalisasi setelah \\
terapi bermain clay
\end{tabular}

Berdasarkan tabel 2 di atas kecemasan pada anak usia pra sekolah (3-6 tahun) yang menjalani hospitalisasi setelah terapi bermain clay dengan nilai rata-rata kecemasan adalah 8.60 .

Tabel 3. Uji Normalitas Data

\begin{tabular}{lcccc}
\hline & Variabel & Skewness & Standar Eror & Hasil \\
\hline Pretest & 0.193 & 0.512 & 0.378 \\
Posttest & 0.06 & 0.512 & 0.117 \\
\end{tabular}


Berdasarkan tabel 3 diatas menunjukkan bahwa uji normalitas data pada variabel sebelum dan setelah dilakukan terapi bermain clay berdistribusi normal dengan hasil semuanya dibawah nilai 2 , jadi analisis bivariat yang digunakan berupa $u j i t$ dependen (uji parametrik).

Tabel 4. Pengaruh terapi bermain clay terhadap kecemasan pada anak usia pra sekolah (3-6 tahun) yang menjalani hospitalisasi di Rumah Sakit Bengkulu

\begin{tabular}{lllll}
\hline $\begin{array}{l}\text { Kecemasan pada anak } \\
\text { usia pra sekolah (3-6 }\end{array}$ & Mean & SD & SE & P value \\
tahun) yang menjalani & & & \\
hospitalisasi & & & & \\
\hline $\begin{array}{l}\text { Sebelum dan setelah } \\
\text { dilakukan terapi bermain }\end{array}$ & 3.150 & 0.813 & 0.182 & \\
clay & & & & 0.000 \\
\hline
\end{tabular}

Berdasarkan tabel 4 di atas diperoleh hasil uji statistik didapatkan nilai $p=0,000$, berarti $<0,05(\alpha)$ sehingga dapat disimpulkan bahwa ada pengaruh terapi bermain clay terhadap kecemasan pada anak usia pra sekolah (3-6 tahun) yang menjalani hospitalisasi di Rumah Sakit Bengkulu.

\section{PEMBAHASAN}

Hasil penelitian menunjukkan bahwa clay therapy dapat mempengaruhui kecemasan anak akibat hospitalisasi, hal ini dilihat dari hasil tabulasi silang antara kecemasan anak akibat hospitalisasi sebelum dan sesudah diberi clay therapy menunjukkan bahwa dari16 anak sebelum diberi clay terapy tingkat kecemasanya dalam kategori sedang, namun setelah diberi clay therapy menjadi ringan, sebagaimana teori diatas menyatakan bahwa clay therapy bermanfaat untuk mengasah kemampuan otak kanan, meningkatkan kreativitas daya imajinasi anak dan melatih kerja syaraf motorik anak, sehingga akan mengurangi kecemasaan pada anak saat menjalani hospitalisasi.

Menurut peneliti permainan clay selain dapat mengembangkan kemampuan motorik halus anak permainan clay juga membuat anak mampu mengenal konsep warna dan bisa mengembangkan imajnasi dan fantasi anak yang dituangkan dalam bentuk clay 
yang ia inginkan. Melalui permainan clay, anak yang berada dalam kondisi stres, dan cemas selama sakit akan lebih santai.

Sebelum diberikan terapi bermain anak mengalami tingkat kecemasan yang lebih tinggi karena pada saat di rumah sakit anak akan menjalani tindakan medis dan biasanya anak menolak untuk dilakukan tindakan medis karena anak beranggapan tindakan medis tersebut akan melukai daerah tubuhnya, sehingga anak menjadi khawatir, ketakutan, menangis, cemas dan selalu ingin berada di dekat orangtua nya sehingga tingkat kecemasan anak sebelum dilakukan terapi bermain akan lebih tinggi. Respon anak terhadap hospitalisasi adalah banyak anak yang sering menolak saat menjalani perawatan dirumah sakit karena anak harus menyesuaikan diri dengan lingkungan rumah sakit yang asing, apalagi harus menjalani rawat inap dalam jangka waktu yang lama. Peralatan medis yang terlihat bersih dan prosedur medis dianggap anak menyakitkan dan bisa membahayakan atau bahkan melukai daerah tubuhnya. Hal inilah yang menimbulkan terjadinya kecemasan hospitalisasi pada anak (Ria Setia Sari \& Fina Afriani, 2019).

Kecemasan sedang memungkinkan seseorang untuk memusatkan pada masalah yang selektif, namun dapat melakukan sesuatu terarah. Manifestasi yang terjadi pada tingkat ini yaitu kelelahan meningkat, kecepatan denyut jantung dan pernafasan meningkat, ketegangan otot meningkat, bicara cepat dengan volume tinggi, lahan persepsi menyempit, mampu untuk belajar namun tidak optimal, kemampuan konsentrasi menurun, mudah tersinggung, tidak sabar, mudah lupa, marah dan menangis. Sedangkan kecemasan ringan berhubungan dengan ketegangan dalam kehidupan keseharianya yang menyebabkan seseorang menjadi waspada dan meningkatkan lahan persepsinya. Manifestasi yang muncul pada tingkat ini adalah kelelahan, kesadaran tinggi, mampu belajar, motivasi meningkat dan tingkah laku sesuai situasi (Nurmayunita, Heny dan Hastuti, 2019).

Bermain Clay akan melepaskan anak dari ketegangan dan kecemasan yang dialami. Karena dengan bermain anak akan dapat mangalihkan rasa sakitnya pada permainan (distraksi) dan relaksasi melalui kesenangannya dalam bermain. Akibat adanya distraksi dan relaksasi yang terjadi, anak yang mengalami cemas akhirnya menjadi tidak cemas lagi. Clay dapat meningkatkan daya pikir anak dan konsentrasi 
anak. Melalui Clay anak akan dapat mempelajari sesuatu yg rumit serta anak akan berpikir bagaimana Clay dapat terbentuk sesuai gambar atau cetakan dengan rapi. Pemberian terapi bermain Clay terhadap dampak hospitalisasi pada anak usia prasekolah yaitu ada pengaruh terhadap penurunan kecemasan, kehilangan kontrol, dan ketakutan pada anak yang dirawat di rumah sakit. Karena bermain merupakan aktivitas yang menyenangkan bagi anak-anak (Nurmayunita, Heny dan Hastuti, 2019).

Bermain clay termasuk dalam jenis bermain aktif. Jenis clay seperti playdough dipilih selain berfungsi sebagai terapi bagi anak juga bermanfaat dalam meningkatkan kemampuan motorik halus anak, mengembangkan kemampuan imajinasi, dan kreativitas anak, karena anak usia prasekolah mengalami perkembangan motorik kasar dan halus dengan cepat serta dapat mengenalkan anak tentang warna. Hal tersebut sesuai dengan yang dikemukakan oleh (Marni, 2018) salah satu permainan yang cocok yang dapat diterapkan untuk anak prasekolah adalah permainan yang dapat merangsang perkembangan motorik halus anak dan permainan yang bersifat membangun sebuah konstruksi (construction play) seperti membuat suatu bentuk tertentu dari adonan/tanah liat/lilin mainan. Oleh karena itu, peneliti memilih jenis terapi bermain clay seperti playdough, karena cocok diberikan pada anak prasekolah (Dayani et al., 2015).

Berdasarkan uraian diatas menunjukkan bahwa rata-rata tingkat kecemasan anak setelah dilakukan terapi bermain mengalami penurunan kecemasan ini disebabkan karena dengan bermain dapat membantu anak untuk mengekspresikan perasaanya melalui kegiatan bermain sehingga anak akan merasa lebih nyaman. Dengan bermain juga dapat mengurangi ketegangan atau kecemasan anak, memberi efek rileks pada anak dan dapat menjadi alat distraksi pada saat anak dilakukan tindakan keperawatan, dan juga dapat menjadi alat distraksi terhadap orang asing atau lingkungan sekitar rumah sakit (Ria Setia Sari \& Fina Afriani, 2019).

Pada masa prasekolah jenis permainan salah satunya adalah skill play. Skill play memberikan kesempatan pada anak untuk memperoleh ketrampilan tertentu dan anak dapat melakukan berulang-ulang (Oktiawati, Khodijah, Setyaningrum \& Dewi, 2017). Salah satu permainan skill play adalah bermain clay. Terapi clay merupakan jenis terapi bermain kreativitas seni dan keahlian. Bermain terapeutik dengan menggunakan clay sangat tepat karena clay tidak membutuhkan energi yang besar untuk bermain, 
meningkatkan kemampuan anak dalam memecahkan masalah, menurunkan kecemasan, pengendalian impuls dan kemarahan (Oktiawati et al., 2020).

Hasil penelitian (Linda et al., 2018), terdapat perbedaan yang signifikan antara nilai pretest-postest pada kelompok perlakuan dan kontrol. Terdapat perbedaan yang signifikan pada selisih pretest dan postest pada kelompok perlakuan dan kontrol. Maka hipotesis dalam penelitian ini diterima yaitu ada pengaruh terapi bermain: clay therapy terhadap perilaku adaptif pada anak usia prasekolah yang mengalami hospitalisasi di Ruang Kaswari RSUD Wangaya Denpasar. Tidak terdapat hubungan yang bermakna antara variabel perancu dengan nilai perilaku adaptif anak.

Penelitian ini juga sejalan dengan penelitian yang dilakukan oleh (Dayani et al., 2015) dengan hasil penelitian rata-rata nilai kecemasan sesudah diberikan terapi bermain adalah 35,23 dengan nilai penurunan sebesar 5,30. Penelitian ini juga sejalan dengan penelitian (Alini, 2017) yang menunjukkan bahwa sebelum diberikan terapi bermain plastisin (playdought) rata-rata tingkat kecemasan responden adalah 9,60 dengan standar deviasi 2,293 dan hasil uji statistik menunjukkan bahwa nilai $\mathrm{P}=0,00$ yang berarti ada perbedaan yang signifikan antara tingkat kecemasan sebelum dan setelah diberikan intervensi terapi bermain plastisin (playdought).

Dalam proses pelakasanaan penelitian, keterbatasan yang dialami peneliti adalah peneliti menggunakan jumlah sampel hanya berjumlah 20 orang. Saat akan dilakukan pelaksanaan penelitian peneliti susah dalam mengkondisikan ruangan yang akan digunakan saat makan melakukan terapibermain karena belum ada ruangan khusu yang bisa digunakan untuk bermain anak yang dirawat.

\section{KESIMPULAN}

Hasil penelitian dapat disimpulkan terdapat penurunan nilai rata-rata kecemasan pada anak usia pra sekolah (3-6 tahun) yang menjalani hospitalisasi sebelum dan setelah terapi bermain clay dan dengan melihat nilai statistik didapatkan bahwa ada pengaruh terapi bermain clay terhadap kecemasan pada anak usia pra sekolah (3-6 tahun) yang menjalani hospitalisasi di Rumah Sakit Bengkulu. 


\section{UCAPAN TERIMA KASIH}

Peneliti mengucapkan terima kasih kepada Direktur Rumah Sakit Bengkulu yang sudah memberikan fasilitas selama proses Penelitian. Yayasan Persada Raflesia dan Ketua STIKES Bhakti Husada Bengkulu.

\section{DAFTAR PUSTAKA}

Alini. (2017). Pengaruh Terapi Bermain Plastisin (Playdought) Terhadap Kecemasan Anak Usia Prasekolah (3-6 Tahun) Yang Mengalami Hospitalisasi Di Ruang Perawatan Anak Rsud Bangkinang Tahun 2017. Occupational Medicine, 53(4), 130.

Dahlan, S. (2014). Statistik Untuk Kedokteran Dan Kesehatan. Edisi 6. Jakarta: Salemba Medika.

Daniel, D. (2021). Terapi Bermain Terhadap Tingkat Kecemasan Anak Prasekolah Yang Mengalami Hospitalisasi : A Literature Review. 6(1).

Dayani, N. E., Budiarti, L. Y., \& Lestari, D. R. (2015). Terapi Bermain Clay Terhadap Kecemasan Pada Anak Usia Prasekolah (3-6 Tahun) Yang Menjalani Hospitalisasi Di Rsud Banjarbaru. Terapi Bermain Clay, 3(2), 1-15.

Linda, K., Savitri, D., Kusumaningsih, F. S., Ayu, D., \& Rama, A. (2018). Pengaruh Clay Therapy Terhadap Perilaku Adaptif Pada Anak Usia Prasekolah Yang Mengalami Hospitalisasi. Community of Publishing in Nursing, 6(3), 2303-1298.

Marni, dkk. (2018). Pengaruh Terapi Bermain Terhadap Penurunan Kecemasan Pada Anak Usia Pra Sekolah. Jurnal Media Kesehatan, 10(2), 185-190. https://doi.org/10.33088/jmk.v10i2.344

Notoatmodjo, S. (2016). Metode Penelitian Kesehatan. Jakarta : Rineka Cipta.

Nurmayunita, Heny dan Hastuti, A. . (2019). Pengaruh Terapi Bermain Clay Terhadap Kecemasan Hospitalisasi Pada Anak Usia 3-6 Tahun. 4(1), 1-10.

Oktiawati, A., Widyantoro, W., \& Fardlillah, A. M. F. (2020). Bermain Terapeutik Clay Menurunkan Tingkat Kecemasan Pada Anak Usia Prasekolah Saat Tindakan Injeksi. Malahayati Nursing Journal, 2(4), 695-704. https://doi.org/10.33024/manuju.v2i4.3013

Ria Setia Sari, \& Fina Afriani. (2019). Terapi Bermain Clay Terhadap Tingkat Kecemasan Pada Anak Usia Prasekolah (3-6 Tahun). Jurnal Kesehatan, 8(1), 5163. https://doi.org/10.37048/kesehatan.v8i1.151

Sudiyanto, H., \& Andrio. (2020). Pengaruh Stimulasi Clay Therapy Terhadap Kecemasan Akibat Hospitalisasi Pada Pasien Anak Usia Prasekolah Di Ruang Anak Rsu Dr. Wahidin Sudiro Husodo. Jurnal Medica Majapahit, 12(2), 59-77.

World Health Organition. (2015). Buku saku pelayanan kesehatan anak. Department of Child and Adolescent Health and Development (CAH). 
Yati, M., Wahyuni, S., \& Islaeli, I. (2017). the Effect of Storytelling in a Play Therapy on Anxiety Level in Pre-School Children During Hospitalization in the General Hospital of Buton. Public Health of Indonesia, 3(3), 96-101. https://doi.org/10.36685/phi.v3i3.134 